\title{
Herbicidal potential of the allelochemicals from Pennisetum purpureum Schumach. on the seedling growth of Paspalum conjugatum
}

\author{
B.S. Ismail ${ }^{1}$, P.W. $\operatorname{Tan}^{1}$, T.S. Chuah ${ }^{2}$, Y. Nornasuha ${ }^{3}$ \\ ${ }^{1}$ School of Environmental and Natural Resource Sciences, Faculty of Science and Technology, Universiti Kebangsaan \\ Malaysia, 43600 UKM Bangi, Selangor, Malaysia \\ ${ }^{2}$ School of Food Science and Technology, Universiti Malaysia Terengganu, 21030 Kuala Terengganu, Terengganu, \\ Malaysia \\ ${ }^{3}$ School of Agricultural Sciences and Biotechnology, Faculty of Bioresource and Food Industry, Universiti Sultan \\ Zainal Abidin, Kampus Besut, 22200 Besut, Terengganu, Malaysia
}

*Corresponding author: ismail@ukm.edu.my

\begin{abstract}
Pennisetum purpureum is one of the invasive weeds in Malaysia. This weed possesses secondary metabolites that could play the role of dominating the ecosystem. Their allelochemicals thus, have potential to be used in herbicidal formulations to control weeds. Therefore, a study was carried out on the potential of the herbicidal activity of the "above-ground" parts of $P$. purpureum in the laboratory and greenhouse using the aqueous extract (@: $0 \mathrm{~g} / \mathrm{L}$ (control), $20 \mathrm{~g} / \mathrm{L}, 40 \mathrm{~g} / \mathrm{L}, 60 \mathrm{~g} / \mathrm{L}, 80 \mathrm{~g} / \mathrm{L}$ and $100 \mathrm{~g} / \mathrm{L}$ ) and debris (incorporated into the soil) (@: $0 \mathrm{~g} / 500 \mathrm{~g}$ (control), $5 \mathrm{~g} / 500 \mathrm{~g}, 25 \mathrm{~g} / 500 \mathrm{~g}$ and $50 \mathrm{~g} / 500 \mathrm{~g}$ (leaf debris/soil)) of $P$. purpureum. The effects of different concentrations of contaminated soil and the root exudate of $P$. purpureum on the seedling growth of the weed bioassay species (Paspalum conjugatum) was studied in an experiment using four replications. Results under laboratory conditions showed that the growth of $P$. conjugatum was inhibited by $100 \%$ at the concentrations of $80 \mathrm{~g} / \mathrm{L}$ and $100 \mathrm{~g} / \mathrm{L}$ of the aqueous extract of $P$. purpureum. Besides, the seedling growth of $P$. conjugatum was inhibited by more than $50 \%$ at the concentration of $50 \mathrm{~g} / 500 \mathrm{~g}$ $(1 / 10)$ of the debris of the above-ground parts of $P$. purpureum to soil, respectively. Moreover the germination and seedling growth of $P$. conjugatum were also inhibited by more than $50 \%$ when planted in $500 \mathrm{~g}$ of infested soil and treated with applications of the root exudate of $P$. purpureum. Results from these studies suggest that $P$. purpureum has herbicidal activity and the potential to be explored further in the search for allelopathic chemicals.
\end{abstract}

Keywords: Pennisetum purpureum, herbicidal activity, Paspalum conjugatum.

Abbreviations: IAA_ indole acetic acid.

Introduction

Plant production systems are currently relying on the use of herbicides for controlling weeds. Herbicides often reach a destination other than their target species, because they are sprayed across entire agricultural fields (Jasieniuk et al., 1996). The excessive use of herbicides in agriculture will lead to the contamination of surface and ground water (Worsham, 1989). Herbicides potentially affect other species through runoff that carry herbicides into aquatic environments (Jasieniuk et al., 1996). Over time, the pervasive use of herbicides for weed control will result in herbicide resistant weeds along with ecological and human health deterioration (Syed et al., 2014). The concept of allelopathy has gained the interest of scientists throughout the world in the attempt to minimize dependency on chemical herbicides for weed control (Om et al., 2002). The term "allelopathy" was coined by Molisch in 1937 from the Greek words allelon (of each other) and pathy (to suffer) to describe the chemical interaction that takes place among plants, including microorganisms (Weston, 2005). The secondary metabolites that are related to this phenomenon are called "allelochemicals" and they are released into the environment by the ecological processes of volatilization, leaching, root exudation, and decomposition of plant residues (Albuquerque et al., 2011). Allelopathy is the inhibitory and/or stimulatory effect of one plant (including microrganisms) on another plant through the release of chemical compounds into the environment (Rice 1984). Allelochemicals can be present in different plant parts such as leaves, stems, flowers, roots and buds (Albuquerque et al., 2011). The allelochemicals have great potential to be used as alternative to herbicides because they are free from the harmful effects compared to the chemical pesticides currently used (Khan et al., 2011).

Allelochemicals have a mode of action similar to that of herbicide (Soltys et al., 2013) and most allelochemicals are either partially or completely water soluble (Dayan et al., 2009). In addition, allelochemicals are reported to have less halogen atoms, complex chemical structures and short half- 
lives in the ecosystem, which makes these naturally produced compounds environmentally friendly and safer compared to those that are manufactured chemically (Duke et al., 2002). Thus, the identification of the compounds that have allelopathic potential can be useful for the development of an alternative approach to combat weed problems (Khan et al., 2011). Allelochemicals have the potential to be developed as natural herbicides or to act as the template in the identification of the active ingredients for the development of new herbicides (Dayan et al., 2012). Pennisetum purpureum Schumach (Family: Poaceae), also known as napier grass is a common weed in Malaysia (Ismail et al., 2015). This weed is native to tropical Africa and the sub-saharan region (Clayton et al., 2013) and was introduced to Malaysia in 1920 as a forage crop for livestock (Anindo and Potter, 1986). This weed can grow well during the drought season (Foxcoft et al., 1983), possessing a thick and strong stem that can reach a height of about 4 to 5 metres (Langeland et al., 2008). Studies carried out by Norhafizah et al. (2013) showed that methanol and aqueous extracts of the "aboveground" parts of $P$. purpureum inhibited the germination of Leptochloa chinensis by $50 \%$ at concentrations of $0.07 \mathrm{~g} / \mathrm{L}$ and $0.47 \mathrm{~g} / \mathrm{L}$ respectively. Field observations showed that there were no other associated plant species growth in areas dominated by P. purpureum. Thus, this weed probably has allelopathic properties that suppress the growth of other plants. Further studies are needed to identify the nature of inhibition by this weed. Reports on the herbicidal effects of $P$. purpureum on weed growth are limited. In the present study, the herbicidal potential of $P$. purpureum was determined using the aqueous extract and debris of the "aboveground" parts, infested soil and root exudate on the seedling growth of the weed, Paspalum conjugatum Bergius.

\section{Results and Discussion}

\section{Effect of the aqueous extract of the "above-ground" parts of Pennisteum purpureum}

Figure 1 and Table 1 shows that the aqueous extract of the above-ground parts of $P$. purpureum significantly inhibited (by $100 \%$ ) the growth (shoot length, radicle length, fresh weight and dry weight) of Paspalum conjugatum at the concentrations of $80 \mathrm{~g} / \mathrm{L}$ and $100 \mathrm{~g} / \mathrm{L}$. However, at the concentration of $20 \mathrm{~g} / \mathrm{L}$, the shoot length of $P$. conjugatum was stimulated by $12.5 \%$ (compared to that of the control). In addition, at the concentration of $40 \mathrm{~g} / \mathrm{L}$, the radicle length was inhibited by $96 \%$ (compared to that of the control), the inhibition was higher than that of the shoot length at same concentration. As the concentration increased, the percentage inhibition on the growth of $P$. conjugatum also increased (Figure 1 and Table 1). The inhibitory factor in the aqueous extract of $P$. purpureum caused growth inhibition of $P$. conjugatum. In another study by Ismail and Chong (2002), it was reported that the inhibition of the radicle length in the bioassay test species was attributed to the presence of allelochemicals in the Mikania micrantha aqueous extract. The presence of allelochemicals in the aqueous extract results in the inhibition of the synthesis of the gibberellin and indole acetic acid (IAA) and this would cause inhibition of the germination process (Moradshahi et al., 2003). The radicle length was more severely inhibited (compared to that of the control) because the radicle had direct contact with the aqueous extract in the petri dish experiment and the radicle consists of tissues that are more permeable to the absorption of allelochemicals compared to those in the shoot (Nishida et al., 2005).

\section{Effect of the debris of the "above-ground" parts of Pennisteum purpureum}

The growth of $P$. conjugatum was completely inhibited when planted in soil treated with plant debris of the above ground parts at the concentration of $50 \mathrm{~g} / 500 \mathrm{~g}$ soil (Table 2). The shoot length, radicle length and fresh weight of $P$. conjugatum were inhibited significantly by more than $50 \%$ compared to that of the control at the debris rate of 25 $\mathrm{g} / 500$ soil. The fresh weight and dry weight of $P$. conjugatum were inhibited by $65 \%$ and $48 \%$ compared to that of the control respectively for the debris rate of $5 \mathrm{~g} / 500 \mathrm{~g}$ soil (Table 2). Shaukat (2002) reported that the increment of debris rate in soil will increase the toxicity of the soil and then cause reduction in the fresh and dry weight of the bioassay species tested. Jabeen et al. (2013) reported that low debris rate stimulated the growth due to the presence of organic matter, but higher debris rate caused toxicity.

\section{Effect of soil infested with Pennisteum purpureum}

Table 3 shows that there was significant difference in the shoot length, radicle length and fresh weight of $P$. conjugatum compared to that of the control when seeds were sown in soil infested with $P$. purpureum. The shoot length, radicle length and fresh weight of $P$. conjugatum (when sown in soil infested with $P$. purpureum) were inhibited by $40 \%, 43 \%$ and $81 \%$ compared to that of the control respectively (Table 3 ). The results suggest that $P$. purpureum could cause inhibitory effects on the growth of $P$. conjugatum. Results from the present study are in consonance with those of another study by Ismail and Sugau (1993) where dry matter production in spinach and chinese cabbage where reduced when grown in soil infested with Lantana camara.

\section{Effect of root exudate of Pennisteum purpureum}

There was significant difference in the shoot length, radicle length and fresh weight of $P$. conjugatum compared to that of the control when the seedlings were watered with the root exudate of $P$. purpureum (Table 4). The root exudate of $P$. purpureum inhibited the shoot length, radicle length and fresh weight of $P$. conjugatum by $75 \%, 51 \%$ and $84 \%$ compared to that of the control respectively (Table 4). This could be due to presence of allelochemicals in the root exudate. Growth inhibition occurs when the allelochemicals are released in sufficient concentrations that reach the target species (Newman, 1978). Momilactone B, released into the environment from the root of paddy was found to inhibit the growth of other species surrounding it (Katonoguchi, 2003). Flores et al. (1999) reported that any plant root exudate has the ability to stimulate the expression of pathogenic microbes and this might lead to growth inhibition of the test species. 
Table 1. Effects of different concentrations of aqueous extracts of the "above-ground" parts of Pennisetum purpureum on the seedling growth of Paspalum conjugatum.

\begin{tabular}{|c|c|c|c|c|}
\hline $\begin{array}{l}\text { Concentration } \\
(\mathrm{g} / \mathrm{L})\end{array}$ & $\begin{array}{l}\text { Shoot length } \\
(\mathrm{cm})\end{array}$ & $\begin{array}{l}\text { Radicle } \\
(\mathrm{cm})\end{array}$ & Fresh weight (g) & Dry weight (g) \\
\hline 0 & $0.8 \pm 0.2 b$ & $2.3 \pm 0.8 a$ & $0.0018 \pm 0.0009 a$ & $0.0002 \pm 0.0004 a$ \\
\hline 20 & $0.9 \pm 0.6 a$ & $0.3 \pm 0.2 b$ & $0.0013 \pm 0.0010 b$ & $0.0001 \pm 0.0003 a$ \\
\hline 40 & $0.4 \pm 0.5 c$ & $0.1 \pm 0.1 c$ & $0.0006 \pm 0.0009 c$ & $0.0001 \pm 0.0003 a$ \\
\hline 60 & $0.1 \pm 0.2 d$ & $0.0 \pm 0.1 c$ & $0.0002 \pm 0.0005 d$ & $0.0000 \pm 0.0000 b$ \\
\hline 80 & $0.0 \pm 0.0 \mathrm{e}$ & $0.0 \pm 0.0 c$ & $0.0000 \pm 0.0000 \mathrm{e}$ & $0.0000 \pm 0.0000 b$ \\
\hline 100 & $0.0 \pm 0.0 \mathrm{e}$ & $0.0 \pm 0.0 c$ & $0.0000 \pm 0.0000 \mathrm{e}$ & $0.0000 \pm 0.0000 b$ \\
\hline
\end{tabular}

Note: Means \pm (SD) values followed by the same alphabet within each column are not significantly different at $\rho<0.05$ according to ANOVA and Duncan's multiple range test.

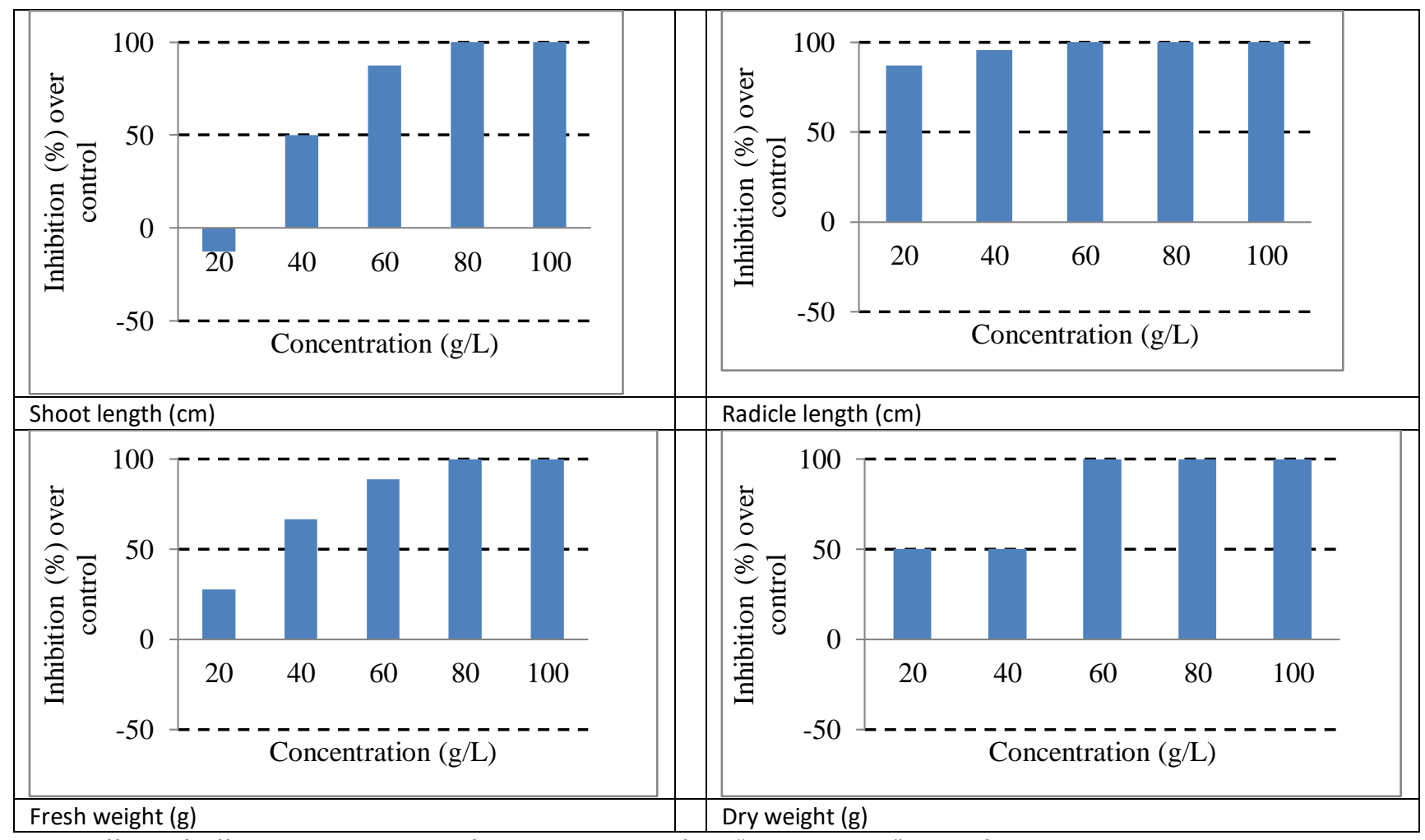

Fig 1. Effects of different concentrations of aqueous extracts of the "above-ground" parts of Pennisetum purpureum on the seedling growth of Paspalum conjugatum. Note: Means \pm (SD) values followed by the same alphabet within each column are not significantly different at $\rho<0.05$ according to ANOVA and Duncan's multiple range test.

Table 2. Effects of different rates of debris of the "above-ground" parts of Pennisetum purpureum on the seedling growth of Paspalum conjugatum.

\begin{tabular}{|c|c|c|c|c|}
\hline $\begin{array}{l}\text { Debris rate } \\
\text { (g/500 g soil) }\end{array}$ & Shoot length $(\mathrm{cm})$ & $\begin{array}{l}\text { Radicle } \\
(\mathrm{cm})\end{array}$ & Fresh weight (g) & Dry weight (g) \\
\hline 0 & $2.7 \pm 0.03 a$ & $7.6 \pm 0.14 a$ & $0.0262 \pm 0.0007 a$ & $0.0060 \pm 0.0019 a$ \\
\hline 5 & $1.5 \pm 0.02 b$ & $5.0 \pm 0.10 b$ & $0.0091 \pm 0.0003 b$ & $0.0031 \pm 0.0011 c$ \\
\hline 25 & $0.4 \pm 0.04 c$ & $2.0 \pm 0.19 c$ & $0.0016 \pm 0.0002 c$ & $0.0048 \pm 0.0008 b$ \\
\hline 50 & $0.0 \pm 0.00 \mathrm{~d}$ & $0.0 \pm 0.00 \mathrm{~d}$ & $0.0000 \pm 0.0000 c$ & $0.0000 \pm 0.0000 d$ \\
\hline
\end{tabular}

Note: Means \pm (SD) values followed by the same alphabet within each column are not significantly different at $\rho<0.05$ according to ANOVA and Duncan's multiple range test.

Table 3. Effects of Pennisetum purpureum- infested soil on the seedling growth of Paspalum conjugatum.

\begin{tabular}{|c|c|c|c|c|c|}
\hline Type of soil & Shoot length $(\mathrm{cm})$ & $\begin{array}{l}\text { Radicle } \\
(\mathrm{cm})\end{array}$ & length & Fresh weight (g) & Dry weight (g) \\
\hline Control & $2.5 \pm 0.5 a$ & $8.0 \pm 1.7 a$ & & $0.021 \pm 0.007 a$ & $0.0043 \pm 0.0002 a$ \\
\hline Soil infested & $1.5 \pm 0.8 b$ & $4.6 \pm 2.0 b$ & & $0.004 \pm 0.002 b$ & $0.0022 \pm 0.0004 a$ \\
\hline
\end{tabular}


Table 4. Effects of the root exudate of Pennisetum purpureum on the seedling growth of Paspalum conjugatum.

\begin{tabular}{|c|c|c|c|c|c|}
\hline Type of exudate & Shoot length $(\mathrm{cm})$ & $\begin{array}{l}\text { Radicle } \\
(\mathrm{cm})\end{array}$ & length & Fresh weight (g) & Dry weight (g) \\
\hline Control & $6.1 \pm 2.1 \mathrm{a}$ & $14.8 \pm 5.8 \mathrm{a}$ & & $0.0360 \pm 0.009 a$ & $0.0033 \pm 0.0002 a$ \\
\hline Root exudate & $1.5 \pm 1.6 b$ & $7.2 \pm 3.7 b$ & & $0.0059 \pm 0.004 b$ & $0.0021 \pm 0.0002 a$ \\
\hline
\end{tabular}

Note: Means $\pm(\mathrm{SD})$ values followed by the same alphabet within each column are not significantly different at $\rho<0.05$ according to T-test.

\section{Materials and Methods}

\section{Materials}

In the study, Pennisetum purpureum was used as the donor plant, whilst Paspalum conjugatum was the recipient. The above-ground parts, infested soil and root exudate of $P$. purpureum were collected from the greenhouse wasteland area of the Universiti Kebangsaan Malaysia (UKM) Bangi $\left(2^{\circ}\right.$ $\left.55^{\prime} 35.2^{\prime \prime} \mathrm{N} 101^{\circ} 45^{\prime} 52.0^{\prime \prime} \mathrm{E}\right)$ from June 2011 until June 2012. $P$. conjugatum seeds were collected from the same location but from a different area and soaked in $0.1 \% \mathrm{KNO}_{3}$ for 72 hours to break the seed dormancy (Gholinejad et al., 2012). The above-ground parts of $P$. purpureum were air dried for 96 hours prior to usage. The experiment on the effect of debris, infested soil and root exudate of $P$. purpureum on the growth of $P$. conjugatum was carried out in the greenhouse at UKM Bangi (temperature: $25-39{ }^{\circ} \mathrm{C}$, light density: $700 \pm 250 \mu \mathrm{Em}^{-2} \mathrm{~s}^{-2}$, and relative humidity: $60 \%$ ).

\section{Laboratory bioassay}

The preparation method for the aqueous extract was a modification of the method of Ismail and Chong (2002). Approximately $10 \mathrm{~g}$ of the dried ground "above-ground" parts of $P$. purpureum were soaked in $100 \mathrm{~mL}$ distilled water and shaken for 48 hours at room temperature $\left(28 \pm 2{ }^{\circ} \mathrm{C}\right)$ on an orbital shaker (150 rpm, Firstek Scientific Model S102, Hsin Chuang, Taiwan). The extract was then filtered through cheese cloth and centrifuged (Jouan MR 14.11) for 15 min at $9000 \mathrm{rpm}$. The supernatant was filtered through $0.22 \mu \mathrm{m}$ filter (Minisart ${ }^{\circledR}-R C / S R P$, Sartorius) prior to use. Six concentrations of the aqueous extract were prepared: $0 \mathrm{~g} / \mathrm{L}$ (distilled water as control), $20 \mathrm{~g} / \mathrm{L}, 40 \mathrm{~g} / \mathrm{L}, 60 \mathrm{~g} / \mathrm{L}, 80 \mathrm{~g} / \mathrm{L}$ and $100 \mathrm{~g} / \mathrm{L}$. Fifty seeds of $P$. conjugatum were sown on filter paper (Whatman No. 1) which had been separately moistened with $5 \mathrm{~mL}$ of each of the different concentrations of the aquoues extracts, in petri dishes (Diameter $9 \mathrm{~cm}$ ). The petri dishes were incubated at $28 \pm 2^{\circ} \mathrm{C}$ (12 hour photoperiod) and examined daily. The seedling growth parameters were recorded at ten days after sowing.

\section{Pennisteum purpureum leaf debris}

The ground, dried "above-ground" parts of $P$. purpureum were incorporated into the soil at different concentrations; 0 $\mathrm{g} / 500 \mathrm{~g}$ (control), $5 \mathrm{~g} / 500 \mathrm{~g}, 25 \mathrm{~g} / 500 \mathrm{~g}$ and $50 \mathrm{~g} / 500 \mathrm{~g}$ (leaf debris/soil). The soil used was classified as the Selangor Series ( $46 \%$ sand, $39 \%$ clay and $15 \%$ silt) and $500 \mathrm{gm}$ soil was filled into each black polybag (height $12 \mathrm{~cm} \times$ diameter 8 $\mathrm{cm}$ ). Fifty seeds of $P$. conjugatum were sown at the depth of $2 \mathrm{~mm}$ below the soil surface in each polybag. The polybags were watered twice daily and seedling growth was recorded at 30 days after sowing (Ismail and Chong, 2002).

\section{Pennisetum purpureum-infested soil}

The samples of soil infested with Pennisetum purpureum ( $66 \%$ sand, $21 \%$ clay, $12 \%$ silt and $\mathrm{pH} 4.66$ ) were collected from 0 until $10 \mathrm{~cm}$ depth from the greenhouse wasteland area of UKM Bangi. The uninfested soil samples ( $84 \%$ sand, $8 \%$ clay, $8 \%$ silt and $\mathrm{pH} 5.89$ ) were collected from the same field and same depth, but from areas without Pennisetum infestation and these served as control. Both soil samples were collected one week after the rain so as to minimize loss of allelochemicals due to leaching by rain water (Inderjit and Duke, 2003). Both sets of soil samples were filtered through $2 \mathrm{~mm}$ filter and used immediately. Fifty seeds of $P$. conjugatum were sown at the depth of $2 \mathrm{~mm}$ from the soil surface in each black polybag (height $12 \mathrm{~cm} \times$ diameter $8 \mathrm{~cm}$ and containing $500 \mathrm{gm}$ soil). The polybags were watered twice daily and the seedling growth was recorded at 30 days after sowing (Ismail and Chong, 2002).

\section{Pennisteum purpureum root exudate}

The method of preparation of the root exudate was a modification of that of Liu et al. (2009), using the root soaking procedure. Ten seedlings of $P$. purpureum, at the mature, flowering stage were uprooted randomly from the field. The roots of $P$. purpureum were rinsed with tap water to remove soil and other solid materials, prior to soaking in $1000 \mathrm{~mL}$ distilled water (in darkness) for 10 hours. The roots were then discarded and the exudate was used to water the seeds of $P$. conjugatum. Fifty seeds of $P$. conjugatum were sown at $2 \mathrm{~mm}$ depth in the Selangor series soil (46\% sand, $39 \%$ clay and $15 \%$ silt) in each black polybag of similar dimensions as described earlier. The polybags were watered twice daily and the seedling growth was recorded at 30 days after sowing. The polybags which were not watered by the solution of the root exudate but with regular water of $P$. purpureum served as control.

\section{Statistical analysis}

The experimental design used was the complete randomized block with four replications. All the statistical analyses were carried out using the SPSS version 20.0 (SPSS IBM, Chicago, IL, USA). The experimental data were subjected to the analysis of variance. The means of fresh/dry weight and root/shoot length of the test species were compared to that of the control using the LSD test at the $5 \%$ level of significance.

\section{Conclusion}

In can be concluded that results from the present study provide evidence that the aqueous extract and debris of the "above-ground" parts, infested soil and the root exudate of Pennisetum purpureum possess properties that can inhibit the growth of Paspalum conjugatum. Identification and 
isolation of the allelochemicals involved in the inhibition process will provide basic information for the development of new herbicides.

\section{Acknowledgements}

This research was supported by the Research Grant No. ERGS/1/2013/STG03/UKM/01/1 (STWN) from the Ministry of Education, Malaysia.

\section{References}

Albuquerque MB, Santos RC, Lima LM, Filho PAM, Nogueira RJMC, Câmara CAG, Ramos AR (2011) Allelopathy, an alternative tool to improve cropping systems. A review. Agron Sustain Dev. 31(2): 379-395.

Anindo DO, Potter HL (1986) Milk production from napier grass (Pennisetum purpureum) in a zero grazing feeding system. E Afr Agr Forestry J. 52: 106-111.

Clayton WD, Govaerts R, Harman KT, Williamson $H$, Vorontsova M (2013) World checklist of poaceae. Royal Botanic Gardens, Kew, Richmond, UK.

Dayan FE, Cantrell CL, Duke SO (2009) Natural products in crop protection. Bioorgan Med Chem. 17(12): 4022-4034.

Dayan FE, Owens DK, Duke, SO (2012). Rationale for a natural products approach to herbicide discovery. Pest Manag Sci. 68: 519-528.

Duke SO, Dayan FE, Rimando AM, Shrader K, Aliotta G, Oliva A, Romagni JG (2002) Chemicals from nature for weed management. Weed Sci. 50: 138-151.

Flores HE, Vivanco JM, Loyola-Vargas VM (1999) "Radicle" biochemistry: the biology of root-specific metabolism. Trends Plant Sci. 4: 220-226.

Foxcroft LC, Richardson DM, Wilson JRU (2007) Ornamental plants as invasive aliens: problems and solutions in Kruger National Park, South Africa. Environ Manage. 41(1): 32-51.

Gholinejad B, Farajollahi A, Pouzesh H, Jaffari HJ (2012) Comparative allelopathic effect of Thymus kotschyanus on germination and early growth of Achillea millefolium under laboratory and pot conditions. Annals Biol Res. 3(8): 39783983.

Inderjit and Duke SO (2003) Ecophysiological aspects of allelopathy. Plantarium. 217: 529-539.

Ismail BS, Sugau JB (1993) Allelopathic effect of Lantana (Lantana camara) and Siam Weed (Chromolaena odorata) on selected crops. Weed Sci. 41: 303-308.

Ismail BS, Chong TV (2002) Effect of aqueous extracts and decomposition of Mikania micrantha H.B.K. debris on selected agronomic crops. Weed Biol Manag. 2: 31-38.

Ismail BS, Tan PW, Chuah TS (2015) Assessment of the potential allelopathic effects of Pennisetum purpureum Scumach. on the germination and growth of Eleusine indica (L.) Gaertn. Sains Malays. 44(2): 269-274.

Jabeen N, Ahmed M, Shaukat SS, Iram-Us-Slam (2013) Allelopathic effects of weeds on wheat (Triticum aestivum L.) germination and growth. Pak J Bot. 41: 1677-1683.

Jasieniuk M, Anita L, Brule-Babel, Morrison IN (1996) The evolution and genetics of herbicides resistance in weeds. Weed Sci. 44: 176-193

Kato-Noguchi H (2003) Allelopathic substances in Pueraria thunbergiana. Phytochemistry. 63: 577-580.
Khan MA, Kulsoom MI, Khan R, Khan, SA (2011) Screening the allelopathic potential of various weeds. Pak J Weed Sci Res 17: 73-81.

Langeland KA, Cherry HM, McCormick CM, Craddock-Burks KA (2008) Identification and biology of non-native plants in Florida's natural areas. University of Florida IFAS Extension, Gainesville, Florida, USA.

Liu N, Zhou B, Zhao X, Lu B, Li Y, Hao J (2009) Grafting eggplant onto tomato rootstock to suppress Verticillium dahliae infection: The effect of root exudates. Hortic Sci. 44(7): 2058-2062.

Moradshahi A, Ghadiri H, Ebrahimikia F (2003) Allelopathic effects of crude volatile oil and aqueous extracts of Eucalyptus camaldulensis Dehnh. leaves on crops and weeds. Allelopath J. 12: 189-195.

Newman El (1978) Allelopathy: adaptation or accident? In: Harbone JB (ed) Biochemical aspects of plant and animal co-evolution, Academic Press, London. 327-342.

Nishida NS, Tamotsu N, Nagata C, Saito, Sakai A (2005) Allelopathic effects of volatile monoterpenoids produced by Salvia leucophylla; Inhibition of cell proliferation and DNA synthesis in the root apical meristem of Brassica campestris seedlings. J Chem Ecol. 31: 1187-1203.

Norhafizah MZ, Oh HY, Ismail BS, Chuah TS (2013) Potential of Napier grass (Pennisetum purpureum) extracts as a natural herbicide. Pak J Bot. 45(6): 2095-2100.

Om H, Dhiman SD, Kumar S, Kumar H (2002) Allelopathic response of Phalaris minor to crop and weed plants in ricewheat system. Crop Prot. 21: 699-705.

Rice EL (1984) Allelopathy, 2nd edn. Academic Press, New York.

Shaukat SS, Siddiqui IA, Khan GH, Zaki MJ (2002) Nematicidal and allelopathic potential of Aregemon mexicana, a tropical weed. Plant Soil. 245: 239-247.

Soltys D, Krasuska U, Bogatek R, Gniazdowska A (2013) Allelochemicals as bioherbicides- present and perspectives. In: Price AJ, Kelton JA (eds) Herbicidescurrent research and case studies in use, In tech. 517-542.

Syed S, Al-Haq MI, Zammurad IA, Muhammad A, Razzaq A (2014) Root exudates and leaf leachets of 19 medicinal plants of Pakistan exhibit allelopathic potential. Pak J Bot. 46(5): 1693-1701.

Weston LA (2005) History and current trends in the use of allelopathy for weed management. Hortechnology. 15: 529-534.

Worsham AD (1989) Current and potential technique using allelopathy as an aid in weed management. In: $\mathrm{Chou} \mathrm{CH}$, Waller GR (eds) Phytochemical ecology: allelochemical, mycotoxins, insect pheromones and allomones, Academia Sinica Monography Series 9, Taipei, ROC. 275-291. 